\title{
AMNESTY AND PARDON \\ CONSTITUTIONAL MODELS ON PROTECTING THE RULE OF LAW AND THE RIGHTS OF CONVICTED PERSONS
}

DOI: 10.47743/rdc-2019- 1-0002

Vladimir-Adrian COSTEA ${ }^{1}$

\section{Abstract}

The general objective is to analyze the various constitutional models that can serve as a pattern for revising the Constitution on amnesty and pardon. In our analysis, we refer to two main dimensions: full respect for the rights of convicted persons, namely the imposition of a mechanism to prevent the arbitrary use of constitutional prerogatives to grant amnesty and pardon, which would thus affect the functioning of the rule of law.

The second objective of the research is to develop an optimal framework for reforming the institutions of amnesty and pardon, starting from "good practice models" identified in the European space. We are proposing to bring into discussion a mechanism to prevent institutional missteps resulting from the personal use of the prerogatives for the provision of amnesty and pardon.

Keywords: Constitution; amnesty; pardon; rule of law; clemency

\section{Introduction}

In order to observe the application of the institutions of Amnesty and Pardon in the framework of the rule of law, throughout this paper we shall focus on the constitutional models which institute a diversified array of mechanisms aimed at respecting the laws of convicted persons and protecting the functioning of the rule of law.

The main objective of this paper is the analysis of different constitutional models which may serve as a benchmark for a revision of the Constitution. Throughout our analysis, we relate to two main issues: firstly, the full respect of the rights of convicted persons, secondly, the imposition of a mechanism which aims to prevent the arbitrary

${ }^{1} \mathrm{PhD}$ candidate at the Doctoral School of the Faculty of Political Science of the University of Bucharest (FSPUB), scientific coordinator: Prof. Univ. Dr. Georgeta GHEBREA, e-mail: costea.vladimir-adrian@fspub. unibuc.ro. 
use of constitutional prerogatives of granting amnesty and pardon, which would thus affect the rule of law.

The secondary objective of our research is the creation of a framework for an optimal reformation of the institutions of Amnesty and Pardon, starting from "good practice models" identified throughout the European space. We argue for a mechanism which prevents institutional missteps as a result of the use of the prerogatives regarding the granting of amnesty and pardon (both individual and collective) in personal interest.

We justify our choice of subject as a result of the position and role which Amnesty and Pardon serve within the institutional, territorial and functional framework of the rule of law, taking into account the provision of Law no. 546/2002 on pardoning and the procedure for granting pardon. To this end, we adhere to the point of view espoused by prof. lancu Mândru, according to whom amnesty and pardon "represent one of the most fascinating facets of criminal law", being "situated at the confluence of constitutional law, administrative law, criminal procedure law, philosophy of law, general theory of the state and of the law, history of the state and of the law"2 ${ }^{2}$. Another argument which justifies our choice is the complexity of clemency measures, which produce a strong echo throughout society. Arbitrary use of the prerogatives of granting amnesty and pardon may lead to strong reactions throughout society, thus affecting the functioning of the rule of law.

De omni re scibili, in the academic literature, study of the measures of clemency (especially regarding the prerogative of the president of granting individual pardons) is focused primarily on the American experience. Conversely, the dynamics of clemency measures in the European space is dealt with succinctly, adding a statistic of the number of persons who have been pardoned, without delving into a detailed analysis, which illustrates the effect that these measures have on society, as well as disregarding the evolution of the institutions of individual pardon and collective pardon under the pressure of exogenous factors ${ }^{3}$. We identify a dominant trend throughout research focusing on the European ${ }^{4}$ and American ${ }^{5}$ space to focus on the right of the sovereign in

2 I. Mândru, Amnistia și Grațierea (Amnesty and Pardon), All Educațional Publishing House, Bucharest, 1998, p. 54.

3 See K.D. Moore, Pardons. Justice, Mercy, and the Public Interest, Oxford University Press, New York, Oxford, 1997 [1989]; C. Flanders, Pardons and the Theory of the "Second-Best”, Florida Law Review, Vol. 65, 2013, pp. 1559-1595; W.M. Landes, R.A. Posner, The Economic of Presidential Pardons and Commutations, The Chicago Working Paper Series No. 320 (2D series), January 2007, pp. 1-22; W.F. Duker, The President's Power to Pardon: A Constitutional History, William \& Mary Law Review, Volume 18, Issue 13, Article 3, 1977, pp. 475-538.

4 See A. Nagy, Presidential Pardon and the European Court of Human Rights, pp. 1-12; T. Austin, D. Hummer, The Effect of Legal and Extra-Legal Variables on the Recommending and Granting of a Pardon, Law and Policy, Vol. 22, Nr. (1), January 2000, pp. 49-65; J.C. Baumgartner şi M.H. Morris, Presidential Power Unbound. A comparative Look at Presidential Pardon Power, Politics \& Policy, Vol. 29, Nr. (2), June 2001.

5 See M.C. Love, Reinventing the President's Pardon Power, American Constitution Society for Law and Policy, October 2007, pp. 1-19; M.C. Love, The Twilight of the Pardon Power, Journal of Criminal Law and Criminology, Vol. 100, No. 3, 2010, pp. 1169-1212; A. Eksterowicz , R.N. Rorerts, The specter of presidential pardon, White house Studies Compendium, Vol. 6, 2006, pp. 319-331; W. F. Duker, The President's Power to

\section{CONSTITUTIONAL LAW REVIEW}


granting clemency, which is why the main studies identify the personalization of the institution of individual Pardon. These papers, however, do not take into account the dynamics of individual Pardon or collective Pardon with regard to the social and political context.

In the Romanian space, the main tendency was to offer an absolute right with regard to granting amnesty and pardon, without taking into account the issue of the undermining of the functioning of the rule of law. The reluctance in regulating the prerogatives of granting amnesty and pardon can be explained by the marginal role of this issue on the public agenda, the only notable exception being the pardon and subsequent revocation of pardon for Miron Cozma ${ }^{6}$.

The originality of this research stems from the creation of a framework for the revision of the Constitution in accordance to the popular will expressed through the consultative referendum of May 26 20197, while referring to "good practice models" identified in the European space. We attribute a central role to the undertaking of establishing a balance between the need to guarantee the respect of the rights of convicted persons and the requirement of preventing issues to the functioning of the rule of law. On the one hand, regulations on the issues of amnesty and pardon must not encroach upon the rights of convicted persons to attain a reduction in their sentence as a result of measures of clemency. On the other hand, an amendment of the constitutional framework must be focused on reducing the risk that clemency measures are granted primarily as a consequence of being part of the political entourage of the right-holders.

The main argument deals with the revision of the constitutional framework regarding the act of legislating and legislative delegation in the issue of granting amnesty and collective pardons, by excepting from measures of clemency the right-holders which may directly influence the legislative process regarding the writing, amending and adopting of a law or emergency ordinance. We therefore discuss the necessity of preventing situations in which measures of clemency are employed in a personal interest by the right-holders. With regard to legislation through emergency ordinance, we focus on the objective requirements put forth by Article 115, para. (4) and (6) of the Constitution.

At the same time, the revision model which we suggest distinguishes between discrimination and the responsibility derived from exercising a public office (either

Pardon: A Constitutional History, William \& Mary Law Review, Vol. 18, No. 3, 1977, pp. 475-538; R.E. Barkow, Clemency and Presidential Administration of Criminal Law, New York University Law Review, Vol. 90, June 2015, pp. 802-869.

${ }^{6}$ See Decree No. 1164 regarding the granting of individual pardons from 15 December 2004, published in the Official Gazette, Part I, Year XV, No. 1207 from 16 December 2004 and Decree No. 1173 regarding the repeal of the individual pardons of persons from 17 December 2004, published in the Official Gazette, Part I, Year XV, No. 1219 from 17 December 2004.

7 See Constitutional Court, Decision no.2 of 27 June 2019 regarding compliance with the procedure for organizing and conducting the national referendum of 26 May 2019 and confirming its results, unpublished.

STUDIES AND ARTICLES 
elected or nominated), as a result of the oath of allegiance. For this reason, for people who have been convicted of crimes committed while serving in a public office, we consider that it is necessary to correlate the right to amnesty and pardon with the responsibilities undertaken as a result of holding office, thus limiting said right. The measure in itself does not institute discrimination and can be found, as we shall show throughout this paper, in certain constitutional models. Through this measure we facilitate the depoliticisation of the institutions of amnesty and pardon, while also reinforcing the responsibility one assumes when serving in a public function.

In order to present an overview, we shall analyse the issue of regulating clemency measures in a comparative perspective, underlining the mechanisms and limits of these mechanisms, in order to enable their transposition into Constitutional revision projects. Our research focuses on a corpus of sources gathered from constitutional norms and Constitutional Court decisions on the matter.

\section{The evolution of the legal framework in postcommunist Romania with}

\section{regard to the definition of clemency measures}

Expressis verbis, the institution of pardon has not been adequately regulated in postcommunist Romania, the normative framework lacking unity and presenting the possibility of dysfunctions as a result of adopting contradictory solutions. This aspect was addressed in the Reason exposition of the Draft Law regarding pardoning and the procedure of granting pardon ${ }^{8}$, initiated by Member of Parliament Acsinte Gaspar, according to whom overstepping the legal framework with regard to the granting of pardons is a result of the fact that procedurally, that is regulated in a single decree from $1952^{9}$, which contained summary dispositions, inadequate for the current legislative and institutional framework. Therefore, until the promulgation of Law No. 546/2002, the procedure of granting pardons was regulated by a decree from the year $1952 .{ }^{10}$

According to initiator Acsinte Gaspar (PSD), the new normative framework also regulated "the establishment of types of infractions which do not lead to a revocation of conditional release; (...) establishing elements which must be mentioned in the individual pardon decree, in order to avoid any confusion in its application; excluding

8 Project promulgated on 10 October 2002 by President Ion Iliescu, became Law No. 546/2002 regarding pardoning and the procedure for granting pardon, published in the Official Gazette, Part I, No. 755, from 16 October 2002.

${ }^{9}$ The decree in question is Decree No. 302/1952 regarding the procedure of pardoning, published in the Official Bulletin, Part I, No. 46 from 9 September 1952.

10 The decree was repealed in accordance to art. 22 para. (2) of Law No. 546/2002 regarding pardoning and the procedure for granting pardon, published in the Official Gazette, Part I, No. 755 of 16 October 2002. 
Amnesty and pardon. Constitutional models on protecting...

from the right to collective pardons crimes - enumerated in the law - characterized by a high degree of social danger."11

With regard to this aspect, we note the intervention of MP Lucian Augustin Bolcaş (PRM), according to whom the institution of individual pardon cannot be regulated by law, as it represents "an act of sovereign conscience through which the leader answers only to himself and God"12. Moreover, L.A. Bolcaş addresses the fact that the dynamics of societal life which serves as the foundation of granting collective pardons does not allow for the establishment of ways and conditions for their granting, as such a regulation would restrict the activity of the legislative body ${ }^{13}$. Member of Parliament L.A. Bolcaş's critique neglects, however, the fact that the internal legislation of modern states "includes regulations specific to the granting of individual pardon", whose role is to "limit the discretionary use of these prerogatives, to rationalise and include it in the judicial phenomenon"14.

Conversely, "establishing by law of a direction or even of concrete basis in which pardon may be invoked would prove wholly unrealistic. The overarching character of social relations is opposed to the qualification of these grounds and their restriction to the procrustean bed of the law. In principle, law is created and evolves under a constant pressure of facts. In this area, that of individual pardon, the force of facts is so strong that, with the exception of constitutional regulation, it blocks the creation of law." 15

In the Romanian judicial framework, the regulation of the two criminal law institutions which produce "profound social reactions"16 has been enacted through the Constitutional framework and Law No. 546/2002. The definition of the two institutions of pardon has a common regulation which relates to the effects which these produce and different regulations with regard to the holder of the right of granting pardons.

${ }^{11}$ See Reason exposition of the Draft Law PL No. 546/2001 Legislative proposal regarding pardoning and the procedure for granting pardons, initiated by MP A. Gaspar, accessed 19.09.2016, available at: http://www.cdep.ro/pls/proiecte/upl_pck2015.proiect?cam=2\&idp=2715.

12 "The law is absolutely inadmissible, because it tends to regulate conditions and frameworks for granting individual pardons, and, on the other hand, for collective pardons. Individual pardon has been, for as long as it has existed, not in the history of law but in the history of mankind, an act of sovereign conscience of the ruler, regardless of how he was called: king, voivod, president and so on. You cannot regulate by law a sovereign act of conscience whereby the leader is responsible only in front of himself and God". The intervention of MP Augustin Bolcaş in the plenary session of the Chammber of Deputies, September 102002 regarding the Draft law regarding pardons and the procedure for granting pardons (adopted), accessed 19.09.2016, available at: http://www.cdep.ro/pls/steno/steno2015.stenograma?ids=5327\&idm=7,02\&idl=1.

13 Ibidem.

14 I. Mândru, Amnistia şi grațierea (Amnesty and Pardon), All Educațional Publishing House, Bucharest, 1998, p. 124.

15 Ibidem, p. 160.

${ }^{16}$ Reason exposition for the Draft Law No. 546/2001, Legislative proposal regarding pardoning and the procedure for granting pardons. 
On the one hand, individual pardon and collective pardon are clemency measures which encompass "the suspension, in whole or in part, of the execution of the sentence passed by the court or in commuting it to a lighter sentence" (article 1 of Law 546/2002). On the other hand, the right-holder of individual pardon is the President of Romania (according to article 94, d) of the Constitution of Romania, republished), while Parliament, by organic law, may grant amnesty or collective pardon (according to article 73, para. (3), i) of the Constitution).

With regard to the actors involved in the creation, adoption and promulgation of a law of collective pardon, their number is much larger compared to the number of actors involved in the granting of individual pardons (the President and Prime Minister, through his countersigning of the decree and the Minister of Justice, who issues an advisory opinion). In 2017, the Constitutional Court revoked requests formulated by the president of the Supreme Council of Magistracy ${ }^{17}$ and the Ombudsman ${ }^{18}$ with regard to the competency of the Government to regulate by Emergency Ordinance the provisions of the Criminal Code and the Criminal Procedure Code (according to article 108 para. (3) and article 115 para. (1) - (3) of the Constitution of Romania, republished), thereby consecrating legislative delegation even in the field of criminal policy. We mention that article 15, para. (1) of Law 546/2002 states that "the task of drafting the bill falls to the Minister of Justice". The latter can receive proposals from the General Direction of Penitentiaries/National Administration of Penitentiaries (article 15, para. (2) of Law 546/2002). Subsequently, the bill receives opinions from the Supreme Council of Magistracy and the Ministry of Internal Affairs. It is then debated in the judicial committees of the Chamber of Deputies and the Senate (article 74, para. (5) of the Constitution of Romania, republished), then voted upon by each Chamber (article 75 and 76 of the Constitution). The law of collective pardon is then sent to the President of Romania for promulgation, who can return it to Parliament for re-examination one time (article 77 of the Constitution). In case the Constitutional Court is notified, the judges will analyze the exceptions of unconstitutionality which were invoked (article 146 of the Constitution of Romania).

With regard to inter-institutional collaboration, according to article 6, para. (1) of Law No. 546/2002, the Minister of Justice must submit advisory opinions to the President of Romania - "when [the latter] considers it necessary" - "within 30 days of

${ }^{17}$ See Constitutional Court, Decision no. 63 of February 8, 2017 regarding the requests for the resolution of the legal conflicts of constitutional nature between the executive authority - the Government of Romania, on the one hand, and the legislative authority - the Parliament of Romania, on the other, as well as between the executive authority - the Government of Romania, on the one hand, and the judicial authority - the Superior Council of Magistracy, on the other hand, requests made by the President of the Superior Council of Magistracy, respectively by the President of Romania, published in the Official Gazette, Part I, no. 145 of February 27, 2017.

18 See Constitutional Court, Decision no. 64 of February 9, 2017 regarding the exception of unconstitutionality of the provisions of the Government Emergency Ordinance no. 13/2017 for amending and supplementing Law no. 286/2009 regarding the Criminal Code and Law no. 135/2010 on the Criminal Procedure Code, published in the Official Gazette, Part I, no. 145 of February 27, 2017. 
their request". However, para. (2) of the same article does not mention the explicit obligation of public administration officials, of the person in charge of the detention facility, of judicial and prosecutorial bodies, of police and other public institutions of sending the President of Romania the information requested for military convicts, as a result of the omission of a term for the transmission of said information. According to article 100, para. (2) of the Constitution of Romania, republished, the individual pardon decrees signed by the President must be countersigned by the Prime-Minister.

In the public session of the $9^{\text {th }}$ of May 2005, through Decision no. 2898/2005, the High Court of Cassation and Justice observed the complex nature of individual pardon, as a result of its position in "several branches of law", by offering the right holder "full freedom in evaluating the grounds of pardon"19. Taking into account the institution of countersigning by the Prime Minister of decrees signed by the President of Romania, the definition of the institution of individual pardon is complemented - by the High Court of Cassation and Justice - with the principle of constitutional democracy instituted through indirect parliamentary control, as the prime-minister answers before the legislative for the decree he countersigns:

"the decrees for granting individual pardons are unilateral judicial acts of public law through which two wills are manifest, but which produce the same effect, independent of the fact that they are called complex administrative acts or atypical administrative acts, most certainly, these judicial acts cannot be assimilated to any other category of administrative acts, being the results of constitutional relations between the two heads of the executive on the one hand and Parliament on the other." 20

Narrata refero, we realize that defining clemency measures was not done $a b$ abrupt, rather, at the same time as the capacity for political innovation of the right-holders. Step by step, the prerogatives of the executive with regard to individual and collective pardons were traced out, in a context in which, initially, this prerogative was used while lacking specific regulation, fact which reinforces the argument that the right of making use of that prerogative was wholly discretionary. Modus probandi, regulations and their interpretation with regard to granting amnesty and pardon were based primarily on procedures which must be followed by right-holders, without, however, discussing the essence of the law. In other words, the right holders may pardon any convicted person, as long as they follow current legal procedures.

The exception was, however, represented by the debate in the Plenary of the Constitutional Court on the $18^{\text {th }}$ of July 2019, of two draft laws for the revision of the Constitution of Romania which aimed at, inter alia, "eliminating the attribute of the

19 Decision no. 2890/2005 of the High Court of Cassation and Justice, Administrative and Fiscal Contentious Section, Public hearing from May 9, 2005.

${ }^{20}$ Ibidem.

STUDIES AND ARTICLES 
State of granting amnesty or pardon, both collective and individual, for "acts of corruption" ". ${ }^{21}$ Unanimously, the Court decided that the proposed regulation infringes upon the limits of revision established by article 152, para. (2) of the Constitution. In its interpretation, the Court stated that by prohibiting measures of clemency in cases of persons convicted for acts of corruption violates "the principles of equality, the guarantee of fundamental rights and freedoms as well as human dignity, a supreme value of the Romanian State". ${ }^{22}$ Denying a certain category of convicted persons the right to amnesty and pardon is, in the eyes of the Court, "a suppression of human dignity and of the principle of equality"23. Implicitly, the reasoning of the Court is grounded on the premise that between convicted persons, the principle of equality applies, therefore, regardless of the committed crime and the sentence they received, the right to measures of clemency is present throughout their serving of the sentence.

In order to break this circulus vitiosus, we propose that we relate to the circumstances of the convicted person is at the time of committing the crime, given the additional responsibilities they have assumed. We indicated, therefore, that there is a certain category which besides violating internal legislation - fact which led to the penal proceedings which culminated in a court passing a definitive conviction sentence - has violated certain moral dispositions present in the Constitutional text. Explicitly, we observe the fact that in order to serve in a high public office, persons elected or nominated by a public authority have the obligation of stating an oath of allegiance through which they take upon themselves, inter alia, respecting the Constitution and the law. When they commit a crime while serving their term, and for which they are subsequently convicted, the persons also break their oath of allegiance. With regard to the ethical dimension of granting acts of clemency, we notice that, in genere, the measure aims at "exercising public power for the benefit/in favor of citizens" 24 . The nuance which we propose aims at creating a constitutional framework for the benefit of all citizens, including citizens who may feel injured by the breaking of the oath of allegiance of people who have served in a public capacity. Regardless of the circumstantial aspects of the crime and its nature, we consider that, ad aeternam, the gravest of crimes is the breaking of the oath of allegiance which they swore when assuming office. Limiting the right of amnesty and pardon is not, in this case, a suppression of human dignity and of the principle of equality, rather, it is a moral consequence of the additional obligations specific to serving in a public capacity, which is characterized by the prevalence of the public interest before one's private interest.

${ }^{21}$ See Constitutional Court, "Press release of July 18, 2019". See also the Constitutional Court, Decision no.464 of July 18, 2019 on the legislative proposal to revise the Romanian Constitution [Pl-x 331 / 3.07.2019], published in the Official Gazette No. 646 of 05.08.2019; Constitutional Court, Decision no. 465 of July 18, 2019 on the legislative proposal for the revision of the Romanian Constitution [Pl-x 332 / 3.07.2019], published in the Official Gazette No. 645 of 05.08.2019.

${ }^{22}$ Idem.

${ }^{23}$ Idem.

${ }^{24}$ Idem. 


\section{Self-pardoning and the limits of legislative delegation}

The issue of self-pardoning underlines the situation in which the convicted person found themselves prior to their definitive conviction. Expressis verbis, we refer to the situation where a public office is vacated when the office holder is "indefinitely incapable of performing his duties" (according to article 70 (2), art 97 and article 106 of the Constitution). Individual pardon, according to article 1 of Law no. 546/2002, is only granted "after the conviction is definitive", which is when the vacancy of the public office is noted, which is why we consider that the person who has been definitively convicted may no longer use the prerogative of individual pardon, as the President's mandate has ceased. In the case of collective pardon, according to article 13 para. (1) and (2) of Law 546/2002, the beneficiaries of the measures of clemency are those persons who have been convicted by the court for "crimes committed prior to the date mentioned in the pardon law", when "pardons produce their effects only after the conviction is definitive"25. In other words, collective pardons are granted also for sentences which are not definitive, a situation which would directly place right-holders for granting such measures "indefinitely incapable of performing their duties", leaving them, thus, with the prerogative of granting collective pardons. In order to benefit from measures of clemency, the definitive conviction needs to be within the limits expressly provisioned in the collective pardon law. We therefore note the possibility that clemency measures enacted by the legislator may directly target people close to the parliamentary majority, situation in which the sense and reason of granting collective amnesty or pardon would be perverted. Necessary regulation in this situation should aim at excepting from the effects of clemency measures those persons who hold or have held a high public office at the time of the publication of the bill or its adoption and promulgation. We therefore avoid the situation in which the possible beneficiary could influence the legislative process.

Another difficult situation is presented by the limits of legislative delegation with regard to measures of clemency, taking into account the provisions of article 115 (4) and (6) of the Fundamental Law, which consecrates the Government's prerogative of adopting Emergency Ordinances in the following terms: "The Government may adopt Emergency Ordinances only in extraordinary situations, whose regulation may not be delayed, having the obligation of arguing the emergency within their text. (...) Emergency ordinances may not be adopted in the field of constitutional law, they cannot affect the regime of fundamental state institutions, the rights, liberties and obligations provisioned in the Constitution, electoral rights, and they cannot establish a forceful public appropriation of goods." Grosso modo, the unconstitutionality critique is

25 See Constitutional Court, Decision no. 89 of February 27, 2003 regarding the exception of unconstitutionality of the provisions of art. 8 of Law no. 543/2002 regarding the punishment of certain penalties and the removal of some measures and sanctions, published in the Official Gazette, Part I, No. 200 of March 27, 2003.

STUDIES AND ARTICLES 
primarily levelled on two issues: a) the legality of granting amnesty and collective pardon by the Government, through Emergency Ordinance; b) respecting rights, liberties and duties consecrated by Fundamental law. Notified by the president of the Superior Council of Magistracy ${ }^{26}$ and the Ombudsman ${ }^{27}$ regarding the existence of a constitutional judicial conflict generated by the adoption of Emergency Ordinance $13 / 2017^{28}$, the Constitutional Court rejected the arguments which held that the Government "abrogated powers, attributes or competencies which, according to the Constitution, reside with Parliament"29, concluding that the competency of Government, "which is expressly provisioned by article 115 of the Fundamental Law"30, was exercised. Referring to its own jurisprudence, the Court noted that the conditions consecrated by Decision 255 of 11 May 2005 were fulfilled:

- "an extraordinary situation;

- Whose regulation cannot be delayed

- The emergency be motivated in the ordinance's text"31

In fact, the Government has the possibility of adopting emergency ordinances exclusively in "exceptional situations when regulation cannot be delayed", characterized by the imperative emergency of regulation, defined in the Court's jurisprudence with regard to "the necessity and emergency of the regulation of a situation which, because of its exceptional circumstances, imposes the adoption of an immediate solution, in

${ }^{26}$ Constitutional Court, Decision no. 63 of February 8, 2017 regarding the requests for the resolution of the legal conflicts of constitutional nature between the executive authority - the Government of Romania, on the one hand, and the legislative authority - the Parliament of Romania, on the other, as well as between the executive authority - the Government of Romania, on the one hand, and the judicial authority - the Superior Council of Magistracy, on the other hand, requests made by the President of the Superior Council of Magistracy, respectively by the President of Romania, published in the Official Gazette, Part I, No. 145 of February 27, 2017.

27 Constitutional Court, Decision no. 64 of February 9, 2017 regarding the exception of unconstitutionality of the provisions of the Government Emergency Ordinance no. 13/2017 for amending and supplementing Law no. 286/2009 regarding the Criminal Code and Law no. 135/2010 on the Criminal Procedure Code, published in the Official Gazette, Part I, No. 145 of February 27, 2017.

${ }^{28}$ Government of Romania, Emergency Ordinance no. 14/2017 regarding the repeal of the Government Emergency Ordinance no. 13/2017 for amending and supplementing Law no. 286/2009 regarding the Criminal Code and Law no. 135/2010 regarding the Code of criminal procedure, as well as for amending Law no. 135/2010 on the Criminal Procedure Code, published in the Official Gazette, Part I, No. 101 of February 5, 2017.

${ }^{29}$ Constitutional Court, Decision no. 63 of February 8, 2017 regarding the requests for the resolution of the legal conflicts of constitutional nature between the executive authority - the Government of Romania, on the one hand, and the legislative authority - the Parliament of Romania, on the other, as well as between the executive authority - the Government of Romania, on on the one hand, and the judicial authority - the Superior Council of Magistracy, on the other hand, requests made by the President of the Superior Council of Magistracy, respectively by the President of Romania, published in the Official Gazette, Part I, No. 145 of February 27, 2017.

${ }^{30}$ Ibidem.

31 See Constitutional Court, Decision no. 255 of May 11, 2005 regarding the notification of unconstitutionality of the Law for the approval of the Government Emergency Ordinance no. 100/2004 regarding the passage of some forest lands from the public property of the state and from the administration of the National Forest Registry - Romsilva on the property of the Archdiocese of Suceava and Răduți, published in the Official Gazette, Part I, No. 511 of June 16, 2005. 
Amnesty and pardon. Constitutional models on protecting...

order to avoid a grave infringement of public interest" 32 . The constitutional legitimacy of adopting an emergency ordinance on the issue of collective amnesty and pardon is conditioned by the defense of a public interest which requires a prompt reaction from the Government. ${ }^{33}$ In similar terms to those used by the court, the emergency situation was defined by the Government as being an "exceptional event, of a non-military character, which through its amplitude and intensity threatens the life and health of the population, the environment, important material and cultural values, and, in order to re-establish a state of normality, necessitates the adoption of urgent measures and actions, allocating additional resources and a unitary management of the forces and means involved". 34

The end goal is the immediate cessation of the exceptional situation, an aspect which justifies the fact that regulation can no longer be delayed, in a situation in which the compulsory terms necessary for the adoption of legislation by Parliament and its promulgation by the President directly limits the prompt reaction necessary for the defence of public interest. Invoking the element of opportunity is objective and is regulated in a necessary and univocal way with regard to the moment when provisions of the Emergency Ordinance come into force.

\section{Defining amnesty and pardon in the Constitutions}

\section{of European Union Member States*}

The comparative analysis of different constitutional models helps in forming an overview of different levels of regulation with regard to granting measures of clemency. Utilizing as indicators the level of regulations and the number of levels of decision regarding the granting of amnesty and pardon, we identify four main types of approaches, as follows: A) a low level of regulation which has a single decision level; B) a high level of regulation which has a single decision level; C) a low level of regulation which has two or more decision levels; D) a high level of regulation which has two or more decision levels. Of the 27 Constitutions we have analyzed, model $\mathrm{C}$ can be identified in 12 states while model A in 9 states. Model D includes 6 atypical versions which restrict the right-holders' vocation of granting measures of clemency. Model B,

32 Constitutional Court, Decision no. 65 of June 20, 1995 regarding the constitutionality of the Law for the approval of the Government Emergency Ordinance no. 1/1995 regarding the conditions for the increase of wages in 1995 to the autonomous kings and commercial companies with majority state capital, published in the Official Gazette, Part I, No. 129 of June 28, 1995.

33 Constitutional Court, Decision no. 83 of May 19, 1998 regarding the exception of unconstitutionality of the provisions of the Government Emergency Ordinance no.22 / 1997 for amending and supplementing the Law of the local public administration no. 211 of June 8, 1998.

34 Government of Romania, Emergency Ordinance no. 21/2004 regarding the National Emergency Management System, published in the Official Gazette, Part I, No. 361 of April 26, 2004.

STUDIES AND ARTICLES 
however has not been used by any state, the explanation being that a high level of regulation necessitates the implementation of two or more levels of decision.

Figure no. 1. Bidimensional table of the regulation of measures of clemency in the European space

\begin{tabular}{|c|c|}
\hline Model A & Model B \\
\hline $\begin{array}{l}\text { Croatia, Estonia, Finland, Ireland, Lithuania, } \\
\text { Malta, Portugal, Slovenia, Sweden }\end{array}$ & - \\
\hline Model C & Model D \\
\hline $\begin{array}{c}\text { Austria, Bulgaria, Czech Republic, France, } \\
\text { Germany, Hungary, Italy, Latvia, } \\
\text { Netherlands, Slovakia, Spain, Romania }\end{array}$ & $\begin{array}{c}\text { Belgium, Cyprus, Denmark, Greece, } \\
\text { Luxembourg, Poland }\end{array}$ \\
\hline
\end{tabular}

The main goal of our approach is to identify models characterized by a high degree of regulation with a corresponding two or more levels of decision, which is why we shall focus on model D. We therefore aim to identify possible limits of the restriction of the prerogatives of right-holders with regard to granting measures of clemency as well as including new actors in the decision process.

Grosso modo, limitations target persons who have served in public office. Therefore, in order for ministers of members of the Government to be granted individual pardon, the approval of the decrees by Parliament is necessary (Belgium Article 111 of the Constitution); Denmark - Article 24; Greece - Article 47 para. (1) and (2); Luxembourg - Article 83, while in Poland, "persons who have been condemned by the State Tribunal cannot be pardoned" (article 139 of the Constitution). We mention the fact that "in case of a violation of the Constitution or of laws while in office", the State Tribunal judges "The President of the Republic, the President and members of the Council of Ministers, the President of the National Bank of Poland, the President of the Supreme Chamber of Control, members of the National Council of Broadcasting and Television, persons who have been granted the leadership of a ministry by the Prime Minister, the Supreme Commander of the Armed Forces, (...) Members of Parliament and Senators" (article 198 of the Constitution of the Republic of Poland). We therefore identify two main approaches: On the one hand, in order to pardon a certain category of individuals (who have served in public office), the sovereign needs the approval of Parliament, who thus obtains the right of veto, and in the case of a lack of approval, the sovereign's decision is not legally binding. On the other hand, the right to pardon is completely and directly restricted for a certain category of persons, in this case being no need to include an additional validation of the sovereign's decision.

We observe, however, that at the core of regulations regarding the application of several levels of decision, we mainly find the institution of individual pardon, which is within the rights of the sovereign to grant (represented by the president or the king). 
Amnesty and pardon. Constitutional models on protecting...

Therefore, the legislative is placed on an asymmetrical position, as the decision for granting amnesty and collective pardons can only be rejected once by the sovereign, who does not have an absolute veto. Usually, the sovereign may only return a law to Parliament for re-examination once, and send it to the Constitutional Court for the appraisal of the constitutionality of its provisions.

To serve as example, we enumerate the particular provisions found in the constitutional models which we have analyzed: In Finland, in order to grant individual pardon, the President needs an a-priori opinion from the Constitutional Court (article 105 of the Constitution of the Republic of Finland). Conversely, in the Netherlands, the King may grant pardon only on the recommendation of a court which has been appointed by law (article 122 of the Constitution of the Netherlands). A different limitation of prerogatives can be found in Slovakia, where the President has the right of individual amnesty and pardon, while Parliament only has the right to grant amnesty for contraventions (article 102 para. (1) j), respectively article $119 \mathrm{l}$ ) and art 121 of the Constitution of Slovakia). An atypical regulation can be seen in article 9 of the Constitution of the Kingdom of Sweden, according to which "in exceptional situation, clearly defined by law, the Government may decide the cessation of criminal proceedings".

$\left(^{*}\right)$ References to constitutional norms were obtained from the Constitutions included in Volumes I and II of the Constitutional Codex, The Constitutions of European Union Member States, edited by Ștefan DEACONU (coord.), Ioan MURARU, Elena Simna TĂNĂSESCU and Silviu Gabriel BARBU, Bucharest, Monitorul Oficial R.A., 2015.

\section{An alternative model based on protecting the rule of law and the rights}

\section{of convicted persons}

Through this research, we aim at creating a Constitutional revision model which is in accordance to the popular will expressed through the consultative referendum of May $26^{\text {th }} 2019^{35}$. Our approach aims at striking a balance between the need to guarantee the respect of the rights of convicted persons and the need to prevent missteps in the functioning of the rule of law. We therefore reiterate the principle that regulations regarding amnesty and pardon must not distort the rights of convicted persons to the reduction of their sentence as a result of a measure of clemency. Simultaneously, the main objective of the amendment to the constitutional framework

\footnotetext{
35 See Constitutional Court, Decision No. 2 of June 27, 2019, regarding the observance of the procedure for organizing and conducting the national referendum on May 26, 2019 and the confirmation of its results, unpublished.
} 
is to limit the risk of granting clemency measures arbitrarily, under the influence of the right-holders' political affiliation.

Our model proposes the amendment of the constitutional framework for granting amnesty and pardon, aiming at preventing situations in which clemency measures are granted by the right-holder in his personal interest, being put into a position where they decide if they should (self) pardon or not. In this situation, the public interest is abandoned by the right holders in favor of personal interest. Explicitly, we propose the exception from the effects of measures of clemency of those persons who serve in public office and can directly influence the legislative process with regard to drafting, amending and adopting the bill or Emergency Ordinance.

Referring to the objective requirements provisioned by article 115 para. (4) and (6) of the Fundamental law regarding legislating through Emergency Ordinance, we consider the motivation of the end goal of the Government regarding the cessation of the emergency of the exceptional situation necessary. Exempli gratia, the term for the coming into force of the provisions of the Emergency Ordinance must not be longer than the term necessary to adopt the bill by Parliament and for the President to promulgate it. Of course, justifying the fact that regulation cannot be delayed must be correlated with the existence of an imminent, objective situation, which forces the adoption of immediate solutions only by the Government in order to avoid grave injuries to the public interest. In overview, we note the exceptional character of the Emergency Ordinance, the objective requirements regarding the opportunity of using this instrument being conditioned both by exceptional circumstances which jeopardize the public interest and the impossibility of Parliament to react promptly.

Punctum saliens, the revision model which we propose introduces a distinction between discrimination and additional responsibility imposed by serving as dignitary, as a result of swearing an oath of allegiance. We therefore consider it necessary to correlate the right to amnesty and pardon with regard to the responsibilities one assumes by taking public office, which limits this right. The introduction of this regulation represents a guarantee regarding the depoliticization of the institutions of Amnesty and Pardon, while at the same time reinforcing the responsibility one assumes by serving in a public capacity. Explicitly, holders of public office who are convicted for crimes committed during their term may no longer have the right to pardon (as they have supplemental obligations while serving their term which impose a restriction of one's rights). Irrespective of the committed crime, one must take into account that public interest trumps personal interest when one serves in a public capacity. The accent does not, therefore, fall on the infraction which was committed, or on the sentence which was passed, rather on the responsibilities imposed by the acceptance of public office. 


\section{Conclusions}

In this article, we have illustrated a diversified array of mechanisms and constitutional models which aim at respecting the rights of convicted persons and protecting the functioning of the rule of law. Starting from constitutional models used in EU member states, we have proposed a mechanism aimed at preventing the arbitrary use of the prerogatives of granting amnesty and pardon, which would thus affect the functioning of the rule of law. We have aimed at striking a balance between the need to guarantee the respect of the rights of convicted persons and the need to prevent missteps in the correct functioning of the rule of law.

Our approach was based on the premise that regulation of amnesty and pardon must not distort the right of convicted persons to have their sentence reduced as a result of the adoption of a measure of clemency. At the same time, we have taken into account the societal backlash of granting measures of clemency, which is why we have considered that the amendment of the constitutional framework must aim at reducing the risk that a measure of clemency may be granted primarily on the basis of the political entourage of the right-holders.

The proposed model imposes the exception that persons who may directly influence the drafting, amendment and adoption of a law or of an Emergency Ordinance for measures of clemency from their effects. For this reason, we have debated the need to prevent situations in which clemency measures are granted in personal interest by the right-holders. We consider it both necessary and opportune to clarify the objective requirements provisioned by article 115 para. (4) and (6) of the Constitution regarding legislation through Emergency Ordinance.

Ad finem, the model we propose connects the right to pardon with the responsibilities assumed through an oath of allegiance at the moment one is invested with public authority. We have proposed the limiting of the right to amnesty and pardon of those persons who have been convicted of crimes committed during their term in public office. Through this measure, we aim to facilitate the depoliticisation of the institutions of Amnesty and Pardon while also reinforcing the additional responsibilities one assumes by serving as a public official.

\section{Bibliography}

\section{Primary sources:}

1. Constitutional Codex, The Constitutions of European Union Member States, edited by Ștefan DEACONU (coord.), Ioan MURARU, Elena Simna TĂNĂSESCU and Silviu Gabriel BARBU, Volumes I \& II, Bucharest, Monitorul Oficial R.A., 2015. 
2. Constitutional Court, Decision no. 65 of June 20, 1995 regarding the constitutionality of the Law for the approval of the Government Emergency Ordinance no. 1/1995 regarding the conditions for the increase of wages in 1995 to the autonomous kings and commercial companies with majority state capital, published in the Official Gazette, Part I, No. 129 of June 28, 1995.

3. Constitutional Court, Decision no. 83 of May 19, 1998 regarding the exception of unconstitutionality of the provisions of the Government Emergency Ordinance no.22/1997 for amending and supplementing the Law of the local public administration no. 211 of June 8, 1998.

4. Constitutional Court, Decision no. 89 of February 27, 2003 regarding the exception of unconstitutionality of the provisions of art. 8 of Law no. 543/2002 regarding the punishment of certain penalties and the removal of some measures and sanctions, published in the Official Gazette, Part I, no. 200 of March 27, 2003.

5. Constitutional Court, Decision no. 255 of May 11, 2005 regarding the notification of unconstitutionality of the Law for the approval of the Government Emergency Ordinance no. 100/2004 regarding the passage of some forest lands from the public property of the state and from the administration of the National Forest Registry - Romsilva on the property of the Archdiocese of Suceava and Răduți, published in the Official Gazette, Part I, No. 511 of June 16, 2005.

6. Constitutional Court, Decision no. 63 of February 8, 2017 regarding the requests for the resolution of the legal conflicts of constitutional nature between the executive authority - the Government of Romania, on the one hand, and the legislative authority the Parliament of Romania, on the other, as well as between the executive authority the Government of Romania, on on the one hand, and the judicial authority - the Superior Council of Magistracy, on the other hand, requests made by the President of the Superior Council of Magistracy, respectively by the President of Romania, published in the Official Gazette, Part I, No. 145 of February 27, 2017.

7. Constitutional Court, Decision no. 64 of February 9, 2017 regarding the exception of unconstitutionality of the provisions of the Government Emergency Ordinance no. 13/2017 for amending and supplementing Law no. 286/2009 regarding the Criminal Code and Law no. 135/2010 on the Criminal Procedure Code, published in the Official Gazette, Part I, No. 145 of February 27, 2017.

8. Constitutional Court, Decision no. 2 of June 27, 2019 regarding the observance of the procedure for organizing and conducting the national referendum on May 26, 2019 and the confirmation of its results, unpublished.

9. Constitutional Court, Decision no.464 of July 18, 2019 on the legislative proposal to revise the Constitution of Romania [PI-x 331/3.07.2019], published in the Official Gazette No. 646 of August 52019.

10. Constitutional Court, Decision no. 465 of July 18, 2019 on the legislative proposal for the revision of the Romanian Constitution [PI-x 332/3.07.2019], published in the Official Gazette No. 645 of August 52019. 
Amnesty and pardon. Constitutional models on protecting...

11. Constitutional Court, "Press release of July 18, 2019".

12. Decree no. 302/1952 regarding the procedure of pardon, published in the Official Bulletin, Part I, No. 46 of September 9, 1952.

13. Decree no. 1164 regarding the granting of individual pardons from December 15, 2004, published in the Official Gazette, Part I, Year XV, No. 1207 of December 16, 2004.

14. Decree no. 1173 regarding the repeal of the individual pardon of persons from December 17, 2004, published in the Official Gazette, Part I, Year XV, No. 1219 of December 17, 2004.

15. Exposition of Reasons for the draft Law PL no. 546/2001 Legislative proposal regarding pardoning and the procedure for granting pardons, initiated by the MP Acsinte Gaspar.

16. Government of Romania, Emergency Ordinance no. 21/2004 regarding the National Emergency Management System, published in the Official Gazette, Part I, No. 361 of April 26, 2004.

17. Government of Romania, Emergency Ordinance no. 14/2017 regarding the repeal of the Government Emergency Ordinance no. 13/2017 for amending and supplementing Law no. 286/2009 regarding the Criminal Code and Law no. 135/2010 regarding the Code of criminal procedure, as well as for amending Law no. 135/2010 on the Criminal Procedure Code, published in the Official Gazette, Part I, No. 101 of February 5, 2017.

18. High Court of Cassation and Justice, Administrative and Fiscal Contentious Section, Decision no. 2890/2005, Public hearing from May 9, 2005.

19. Parliament of Romania, Law no. 546/2002, the law on pardoning and the procedure for granting pardons, published in the Official Gazette, Part I, No. 755 of October 162002.

\section{Secondary sources:}

1. AUSTIN, Thomas and Don HUMMER, "The Effect of Legal and Extra-Legal Variables on the Recommending and Granting of a Pardon", Law and Policy, Vol. 22, No. (1), January 2000, pp. 49-65.

2. BARKOW, Rachel E., "Clemency and Presidential Administration of Criminal Law”, New York University Law Review, Vol. 90, June 2015, pp. 802-869.

3. BAUMGARTNER, Jody C. and Mark H. MORRIS, "Presidential Power Unbound. A comparative Look at Presidential Pardon Power", Politics \& Policy, Vol. 29, No. (2), June 2001.

4. DUKER, William F., "The President's Power to Pardon: A Constitutional History", William \& Mary Law Review, Volume 18, Issue 13, Article 3, 1977, pp. 475-538.

5. EKSTEROWICZ, Anthony and Robert N. RORERTS, "The specter of presidential pardon", White house Studies Compendium, Vol. 6, 2006, pp. 319-331. 
6. FLANDERS, Chad, "Pardons and the Theory of the "Second-Best»", Florida Law Review, Vol. 65, 2013, pp. 1559-1595.

7. LANDES, William M. and Richard A. POSNER, "The Economic of Presidential Pardons and Commutations", The Chicago Working Paper Series, No. 320 (2D series), January 2007, pp. 1-22.

8. LOVE, Margaret Colgate, "Reinventing the President's Pardon Power", American Constitution Society for Law and Policy, October 2007, pp. 1-19.

9. LOVE, Margaret Colgate, "The Twilight of the Pardon Power", Journal of Criminal Law and Criminology, Vol. 100, No. 3, 2010, pp. 1169-1212.

10. MÂNDRU, lancu, Amnistia şi Grațierea (Amnesty and Pardon), Bucharest, All Educațional, 1998, p. 54.

11. MOORE, Kathleen Dean, Pardons. Justice, Mercy, and the Public Interest, New York, Oxford, Oxford University Press, 1997 [1989].

12. NAGY, Anita, "Presidential Pardon and the European Court of Human Rights", pp. 1-12. 